\title{
Invasive versus Non Invasive Methods Applied to Mummy Research: Will This Controversy Ever Be Solved?
}

\author{
Despina Moissidou, ${ }^{1}$ Jasmine Day, ${ }^{2}$ Dong Hoon Shin, ${ }^{3}$ and Raffaella Bianucci ${ }^{4,5,6}$ \\ ${ }^{1}$ Department of Histology and Embryology, Medical School, National Kapodistrian University of Athens, \\ 75 M. Asias Street, 11527 Athens, Greece \\ ${ }^{2}$ The Ancient Egypt Society of Western Australia Inc., P.O. Box 103, Ballajura, WA 6066, Australia \\ ${ }^{3}$ Division of Paleopathology, Institute of Forensic Science, Seoul National University College of Medicine, \\ Seoul 110-799, Republic of Korea \\ ${ }^{4}$ Department of Public Health and Paediatric Sciences, Legal Medicine Section, University of Turin, \\ Corso Galileo Galilei 22, 10126 Turin, Italy \\ ${ }^{5}$ Center for Ecological and Evolutionary Synthesis (CEES), Department of Biosciences, University of Oslo, \\ P.O. Box 1066, Blindern, 0316 Oslo, Norway \\ ${ }^{6}$ Anthropologie Bioculturelle, Droit, Ethique et Santé, Faculté de Médecine-Nord, Aix-Marseille Université, \\ 15 boulevard Pierre Dramard, 13344 Marseille Cedex 15, France
}

Correspondence should be addressed to Dong Hoon Shin; cuteminjae@gmail.com and Raffaella Bianucci; raffaella.bianucci@unito.it

Received 18 December 2014; Accepted 21 April 2015

Academic Editor: Timothy G. Bromage

Copyright (C) 2015 Despina Moissidou et al. This is an open access article distributed under the Creative Commons Attribution License, which permits unrestricted use, distribution, and reproduction in any medium, provided the original work is properly cited.

\begin{abstract}
Advances in the application of non invasive techniques to mummified remains have shed new light on past diseases. The virtual inspection of a corpse, which has almost completely replaced classical autopsy, has proven to be important especially when dealing with valuable museum specimens. In spite of some very rewarding results, there are still many open questions. Non invasive techniques provide information on hard and soft tissue pathologies and allow information to be gleaned concerning mummification practices (e.g., ancient Egyptian artificial mummification). Nevertheless, there are other fields of mummy studies in which the results provided by non invasive techniques are not always self-explanatory. Reliance exclusively upon virtual diagnoses can sometimes lead to inconclusive and misleading interpretations. On the other hand, several types of investigation (e.g., histology, paleomicrobiology, and biochemistry), although minimally invasive, require direct contact with the bodies and, for this reason, are often avoided, particularly by museum curators. Here we present an overview of the non invasive and invasive techniques currently used in mummy studies and propose an approach that might solve these conflicts.
\end{abstract}

\section{Introduction}

Mummies represent a unique source of information about past diseases and their evolution. The question as to how to best maintain the integrity of archaeological and anthropological specimens in the course of examining this evidence has been a major cause for dispute among scholars.

The advent of non invasive techniques (e.g., X-ray, CAT scanning, and MRI) for examining mummified remains has been a breakthrough in paleopathology as retrospective diagnoses can now be achieved without dissection.

However, mainly because of the structural differences between modern and ancient soft tissues, the efficiency of non invasive techniques has been questioned repeatedly. Many scholars insist that an accurate diagnosis can be correctly made only through direct examination of the corpse (i.e., autopsy, endoscopy). However, this approach creates concern among curators and archaeologists. 
Here we address the debate from a broader perspective considering the advantages and disadvantages of both invasive and non invasive methods and propose the creation of an examination protocol for the analysis of ancient mummified remains based upon strict scientific and ethical criteria.

\section{The Use of Non Invasive Techniques in Paleopathology}

A new era in mummy studies began when the first group of Egyptian mummies was subjected to computed tomography (CT) in 1979 [1]. Scientists were given the opportunity to inspect the ancient Egyptians' bodies without resorting to the use of invasive methods [2, 3]. Both hard and soft tissues could be differentiated from multiple textile layers and artifacts (amulets, death masks, or portraits) and their pathologies diagnosed.

Although diagenetic alterations of ancient tissues often generate interpretative biases, CT scans have allowed differentiation between tissue structures and embalming materials. Similarly, antemortem traumas could be distinguished from postmortem manipulations associated with the embalming process [4], generating greater knowledge about the ways in which ancient populations treated and preserved their dead.

Artificial mummification is the deliberate act of preservation of a body after death [5]. This practice is aimed at slowing and/or halting soft tissues' degradation [6]. Different types of treatments (e.g., evisceration, use of natron, and coating with complex mixtures with antibacterial and antiputrefactive properties) allowed long-term preservation of the Egyptian mummies $[7,8]$.

Apart from exceptional cases, in which some steps of the mummification procedure were documented (i.e., the coffin of Djedbastiuefankh, Pelizaeus Museum, Hildesheim, Late Period; the Rhind Magical Papyrus, ca. 200 BC; three papyri in Cairo, Durham Oriental and Louvre Museums, around 1st century AD), the Egyptians did not leave written or illustrated records of their mummification methods [5].

Gaps in direct evidence have, therefore, been filled with information derived from numerous written sources. Herodotus (5th century AD) provided the earliest written accounts of mummification (Book II of The Histories). This is coupled with the records of Diodorus Siculus (1st century BC) and further augmented by the writings of Porphyry (3rd century AD). These principal sources have long provided the basis of modern knowledge about Egyptian mummification techniques [9]. CT scans have thus helped scientists and Egyptologists to increase their knowledge, which had hitherto been biased by the cultural stereotyping of Egypt in classical sources. New and more detailed knowledge about the evolution of artificial mummification has emerged [10,11].

Over the last decade, a new generation of CAT scanners with increased power of resolution has been released and virtual autopsy has become one of the basic steps in any scientific investigation of mummified remains [12]. Visualization technology is an efficient tool in hard and soft tissue paleopathology [13]. Dental diseases (e.g., severe teeth abrasion, carious lesions, cists/abscesses, inflammation, and tooth loss) [14] and many degenerative disorders (e.g., rheumatoid arthritis of the Iceman [15], anthropo-paleopathological in Egyptian mummies [16], bone and soft tissue malignant tumours and/or soft tissue adenomas [17], or atherosclerosis $[18,19])$ can now be diagnosed.

The latest developments in CT resolution (MicroCT) have even enabled the observation of architectural structures of bones [20].

Variations in wavelength radiation or use of Terahertz imaging have also been applied to mummified remains. Depending on the degree of hydration of a mummified corpse, this technique enables scientists to distinguish between features of soft tissues or bone and various artifacts, identifying objects [21] wrapped within textiles.

MRI (magnetic resonance imaging) has been similarly advantageous, especially in the study of hydrated mummies (i.e., bog bodies, South Korean mummies) [22]. MRI application on a 17th century Korean body showed unique clear organ structures, which could not be visualized by CT [23]. Less satisfactory results were obtained from MRI applied to dehydrated and embalmed bodies (i.e., Egyptian mummies) [24-26].

Despite the increased use of non invasive techniques, scholars still debate whether virtual inspection should be regarded as the "gold standard" in mummy studies or not.

In general, the CT methodological reference standards applied to the study of ancient remains are those determined from living patients [27]. Any kind of modification to CT scanning methodology (e.g., slice thickness or the introduction of other non invasive methods such as ionizing radiation on mummified cells) is still on an experimental level and is applied mainly in pilot studies of uncertain potential [28].

As a result of the differences between modern and ancient tissues and the absence of well-established methodological standards in mummy studies, misdiagnosis can occur. Gravitational force modifies both the morphology and location of the organs that elapses between burial and exhumation. Organs are displaced to the dorsal portion and their contraction is severe. While the difference in radiodensity is very important at a diagnostic level for living patients, radiodensity does not differ from organ to organ in mummies. Diagenetic processes can be misidentified as pathological conditions and vice versa [20]. To avoid misinterpretations, the complementary use of invasive methods (i.e., endoscopy, histology) is of utmost importance, either to support or to reject an initial diagnosis.

Another problem associated with the exclusive use of non invasive techniques is the lack of multidisciplinarity in teams involved in the interpretations of the data. Valid scientific research should include trained radiologists, whose experience lies mostly in diagnosing living patients, physical anthropologists or paleopathologists, and archaeologists who provide background information [4, 19, 22, 29].

To some extent concerning the scope of non invasive techniques applied to the study of ancient mummies generates confusion; therefore, the scientific purpose of non invasive methods often loses its meaning.

Museum curators and conservation experts usually prefer to resort to CT scanning in order to avoid specimen sampling 
and usually disregard the need for an overall anthropopaleopathological investigation. As a result, the broader use of non invasive techniques has become a fad, a spectacle misused by some scientists and curators for "infotainment" or advertising purposes. In many cases, the motivation for the employment of visual imaging is to take a curious glimpse inside a mummy [12] and perform animated 3D rendering for public display in exhibits rather than acquire sound scientific data.

\section{The Role of Invasive Methods in Mummy Studies}

Prior to recent advances in paleoradiology, invasive methods were the only available means of examining anthropological materials scientifically. Precious information about ancient lifestyles and diseases was acquired over decades, allowing scholars to gain a more profound historical and biological knowledge about populations of the past. The first invasive examination of ancient mummies began during the early 19th century, albeit as a form of public entertainment [2]. Many mummy unwrappings were carried out on the basis of mere curiosity and limited scientific knowledge. Therefore, many specimens were partially or completely destroyed.

Gradually, mummy autopsy became a more meticulous postmortem and provided scientists with information about both pathologies and possible causes of death [30].

Pioneering palaeopathologists adapted modern laboratory techniques to tiny mummified tissue biopsies in order to identify ancient tissue structures. They successfully diagnosed many diseases (e.g., tuberculosis, atherosclerosis, and parasitic diseases) [31-35].

Step by step, scientists have developed new methods to sample inner organ tissues, for example, endoscopy through natural orifices (i.e., mouth, nasal cavities, and use of forceps), and have progressively reduced the damage caused to mummies $[36,37]$.

Where endoscopes could not be introduced through natural or postmortem openings, a small perforation was made in the mummy's back [38], so that tissue samples could be taken for histological studies.

As in forensic pathology [39], microscopic examination of small tissue biopsies $(0.7 \times 0.7 \mathrm{~cm})$ is a requisite to complement non invasive methods because it allows an initial diagnosis to be precisely confirmed or infirmed [17, 35, 40, 41].

Similar developments in gas chromatography/mass spectrometry (GC/MS), isotopic analysis, and synchrotron analysis of minimal amounts of mummy hair have provided remarkable information about the daily lives of ancient populations within various social classes [42-44] and detected chronic or acute exposure to heavy metals [45-47].

Advances in paleoimmunology [48-50] and paleomicrobiology through soft/hard tissue analysis and secretion swabs led to the retrospective diagnosis of several pathogens (e.g., salmonellosis, tuberculosis, malaria, human leishmaniasis, and Chagas disease) in mummies [51-67] and revealed some of their evolutionary patterns [68]. However, not all scientists agree that it is possible to recover ancient endogenous human and pathogenic DNAs from Egyptian mummies [69-71].
Sampling of small skin tissue biopsies $(0.7 \times 0.7 \mathrm{~cm})$ and textiles $(1 \times 1 \mathrm{~cm})$ proved to be a reliable method for assessing potential biodeterioration of a mummified body or its external contamination. Microorganism identification through cultivation and molecular techniques is extremely useful for conservation purposes and to minimize the risk of potential hazards to the public, especially when mummies are on display [72].

Biochemical investigations (a combination of gas chromatography-mass spectrometry, GC-MS, and thermal desorption/pyrolysis, TD/Py-GC-MS) applied to skin and textiles and to dental calculus provide a plethora of information concerning the recipes used in embalming procedures [73-77] and the diets of ancient populations [78, 79].

Nowadays, the use of invasive methods for examining mummies is widely regarded with skepticism. While some researchers consider autopsies unavoidable, many consider them a destructive procedure [80].

Full autopsy has often been performed mainly to see inside a mummy and take samples for experimental research rather than obtain confirmation of a disease tentatively identified via a non invasive method.

The archaeological value of a human/animal specimen must always be a primary concern, especially when it is on display. When mummies are completely wrapped, fully dressed, and accompanied by funerary equipment, the prospect of a full autopsy threatens their integrity [20]. Whereas CT imaging requires only careful transportation of the mummy, invasive examination is more complex but can potentially be performed in a manner that respects the integrity of the corpse [29].

Equally significant is the ethical issue concerning lack of respect for a human body. A mummy is a deceased person, not an artifact, and burial customs should not be ignored [81]. If this assumption is followed, no sampling or limited sampling should be allowed in order to respect the deceased, and it is equally true that presenting $3 \mathrm{D}$ virtual renderings of undressed dead bodies to a lay public also raises ethical concerns.

Questions concerning the analyses of anthropological remains have been raised in many countries and these call for a specific set of bioethical guidelines [82].

The extent of invasive examination to which ancient mummies should be subjected is the cause of much debate. In the absence of specific laboratory guidelines and protocols, there is a lack of consistency; this has allowed people without sufficient if any scientific background to decide how valuable samples should be investigated. In most countries, decisions rely mostly upon the protocols established by individual institutes, museums, or team supervisors. Decisions based upon such independent judgments may therefore vary from full autopsy permission to total prohibition of the use of any invasive technique.

\section{Discussion and Conclusion}

4.1. Is the Examination Method the Real Issue? The controversy over the necessity of invasive versus non invasive 
techniques calls for some appropriate and standardized protocols to be applied to mummy research. The issue is not the effectiveness of invasive or non invasive studies but their suitability for mummy research, which at present does not consistently achieve scientific standards.

Firstly, the purposes of many studies are inconsistent. A mummy must be investigated in order to provide scholars with answers related to specific biological or historical questions. An investigation performed simply to observe a mummy macroscopically or microscopically is not useful and is not ethical. Curiously, only a limited number of studies focusing upon specific diseases or historical developments in funerary artifact types found upon mummies have been performed to date.

Secondly, artificial mummification techniques vary considerably according to environmental conditions and cultural practices. Various factors, temperature, humidity, soil acidity, and time, cause various cell system modifications; these can be pinpointed both through invasive and non invasive techniques. The state of preservation, fully intact or partially preserved, is significant even for mummies of similar type, which means that every mummy is a unique case.

Despite the numerous studies performed upon mummies, methodological consistency and scientific comparison are lacking. Validity of results cannot be cross-checked for the lack of comparative studies and when scientists from various disciplines collaborate in multidisciplinary studies, conflict of interests is not uncommon.

4.2. Mummy Research Guidelines: The Need for an International Ethical and Scientific Committee. The aim of this review is to show that the current controversy is mainly caused by a lack of internationally established guidelines in mummy research. This, in turn, calls for an international mummy research protocol to be instituted. Composed of scholars of high repute, whose integrity is widely recognized, a committee should reestablish a series of priorities in the study of mummified bodies.

Firstly, ethical issues should be considered [83]. Scientists need to pay respect to the funerary beliefs of the deceased. With advice from cultural anthropologists, ethnologists, and bioethicists, a specific protocol to approach each type of cultural/religious context should be designed.

Secondly, mummy studies should be allowed for scientific and educational purposes but not for business (i.e., public entertainment or commercial movies). The purpose of a given study, either medical or archaeological, should be disclosed before any kind of investigation is performed, its value being widely recognized by the scientific community. Similarly, as many neophytes approach the field without proper training, strict selection criteria should be applied.

Obviously, it is impossible to apply a rigid and inflexible scientific protocol to all mummy cohorts. While some universal principles and rules will apply, technical protocols will necessarily need to be adjusted depending upon the type of mummy (i.e., dry or hydrated) and its state of preservation (i.e., fully wrapped, intact, partially destroyed, etc.). Nonetheless, all parameters used for mummy investigations should be clearly detailed and results fully published.
More transparency should be demanded when genetic studies are released. Entire datasets should be published rather than selected sequences. This would enable other researchers to provide the scientific community with their own interpretations and critical assessments of the data. The absence of transparency through selective data publication only gives rise to accusations of secrecy that taint the name of science and reputation of the data.

Along with an international protocol for mummy investigations, the creation of a worldwide network of tissue banks would be an optimal solution. Scientists could be provided with samples for laboratory research without frequent examination of the original remains [84] and their research would generate a comparative database with which to enable more targeted scientific applications.

Mummies represent the most precious anthropological material with which ancient cultures have provided us. Since mummified bodies attract scientists from different fields, an international protocol is now essential and required urgently. This protocol should clearly answer three main questions: "Are we showing adequate respect to the corpse we are analyzing?", "Which scientific hypothesis necessitates our study of mummified remains?", and "Do we propose to study mummies for scientific/cultural purposes or for business?"

With the aim of creating a scientific committee and, subsequently, of promoting the standardisation of a bioethical protocol on mummified remains, the authors plan to organise a dedicated symposium within the next World Congress on Mummy Studies (Lima, July 27-30, 2016).

\section{Conflict of Interests}

The authors declare that there is no conflict of interests.

\section{Authors' Contribution}

Despina Moissidou, Jasmine Day, Dong Hoon Shin, and Raffaella Bianucci all contributed equally to this work.

\section{References}

[1] D. C. F. Harwood-Nash, "Computed tomography of ancient Egyptian mummies," Journal of Computer Assisted Tomography, vol. 3, no. 6, pp. 768-773, 1979.

[2] A. R. David, The Manchester Museum Mummy Project, Manchester University Press, Manchester, UK, 1979.

[3] D.-S. Lim, I. S. Lee, K.-J. Choi et al., "The potential for noninvasive study of mummies: validation of the use of computerized tomography by post factum dissection and histological examination of a 17th century female Korean mummy," Journal of Anatomy, vol. 213, no. 4, pp. 482-495, 2008.

[4] A. D. Wade and A. J. Nelson, "Radiological evaluation of the evisceration tradition in ancient Egyptian mummies," HOMOJournal of Comparative Human Biology, vol. 64, no. 1, pp. 1-28, 2013.

[5] S. Ikram, Death and Burial in Ancient Egypt, Longman, Harlow, UK, 2003. 
[6] N. Shved, C. Haas, C. Papageorgopoulou et al., "Post mortem DNA degradation of human tissue experimentally mummified in salt," PLoS ONE, vol. 9, no. 10, Article ID e110753, 2014.

[7] B. Brier and R. S. Wade, "The use of natron in human mummification: a modern experiment," Zeitschrift für Ägyptische Sprache und Altertumskunde, vol. 124, no. 2, pp. 89-100, 1997.

[8] S. A. Buckley and R. P. Evershed, "Organic chemistry of embalming agents in Pharaonic and Graeco-Roman mummies," Nature, vol. 413, no. 6858, pp. 837-841, 2001.

[9] S. Wisseman, "Preserved for the afterlife," Nature, vol. 413, no. 6858, pp. 783-784, 2001.

[10] R. Gupta, Y. Markowitz, L. Berman, and P. Chapman, "Highresolution imaging of an ancient Egyptian mummified head: new insights into the mummification process," American Journal of Neuroradiology, vol. 29, no. 4, pp. 705-713, 2008.

[11] A. D. Wade, G. J. Garvin, J. H. Hurnanen et al., "Scenes from the past: multidetector CT of Egyptian mummies of the Redpath Museum," Radiographics, vol. 32, no. 4, pp. 1235-1250, 2012.

[12] J. J. O’Brien, J. J. Battista, C. Romagnoli, and R. K. Chhem, "CT imaging of human mummies: a critical review of the literature (1979-2005)," International Journal of Osteoarchaeology, vol. 19, no. 1, pp. 90-98, 2009.

[13] A. S. Wilson, "Digitised diseases: preserving precious remains," British Archaeology, vol. 136, pp. 36-41, 2014.

[14] L. Pacey, "Ancient mummies reveal impact of dental disease," British Dental Journal, vol. 216, no. 12, p. 663, 2014.

[15] R. Ciranni, F. Garbini, E. Nerie, L. Melai, L. Giusti, and G. Fornaciari, "The 'Braids lady' of Arezzo: a case of rheumatoid arthritis in a 16th century mummy," Clinical and Experimental Rheumatology, vol. 20, no. 6, pp. 745-752, 2002.

[16] W. K. Taconis and G. J. R. Maat, "Radiological findings in the human mummies and human heads," in Egyptian Mummies: Radiological Atlas of the Collections in the National Museum of Antiquities at Leiden, J. R. Maarten, W. K. Taconis, and G. J. R. Maat, Eds., Brepols, Turnhout, Belgium, 2005.

[17] G. Fornaciari, M. Castagna, A. Naccarato, P. Collecchi, A. Tognetti, and G. Bevilacqua, "Adenocarcinoma in the mummy of Ferrante I of Aragon, King of Naples," Paleopathology Newsletter, vol. 82, pp. 7-11, 1993.

[18] A. H. Allam, R. C. Thompson, L. S. Wann, M. I. Miyamoto, and G. S. Thomas, "Computed tomographic assessment of atherosclerosis in ancient Egyptian mummies," Journal of the American Medical Association, vol. 302, no. 19, pp. 2091-2094, 2009.

[19] R. C. Thompson, A. H. Allam, G. P. Lombardi et al., "Atherosclerosis across 4000 years of human history: the Horus study of four ancient populations," The Lancet, vol. 381, no. 9873, pp. 1211-1222, 2013.

[20] N. Lynnerup, "Mummies," Yearbook of Physical Anthropology, vol. 50, pp. 162-190, 2007.

[21] L. Öhrström, A. Bitzer, M. Walther, and F. J. Rühli, “Technical note: terahertz imaging of ancient mummies and bone," American Journal of Physical Anthropology, vol. 142, no. 3, pp. 497-500, 2010.

[22] C. Papageorgopoulou, K. Rentsch, M. Raghavan et al., "Preservation of cell structures in a medieval infant brain: a paleohistological, paleogenetic, radiological and physico-chemical study," NeuroImage, vol. 50, no. 3, pp. 893-901, 2010.

[23] D. H. Shin, I. S. Lee, M. J. Kim et al., "Magnetic resonance imaging performed on a hydrated mummy of medieval Korea," Journal of Anatomy, vol. 216, no. 3, pp. 329-334, 2010.
[24] H. Piepenbrink, J. Frahm, A. Haase, and D. Matthaei, "Nuclear magnetic resonance imaging of mummified corpses," American Journal of Physical Anthropology, vol. 70, no. 1, pp. 27-28, 1986.

[25] F. J. Rühli, R. K. Chhem, and T. Böni, "Diagnostic paleoradiology of mummified tissue: interpretation and pitfalls," Canadian Association of Radiologists Journal, vol. 55, no. 4, pp. 218-227, 2004.

[26] S. J. Karlik, R. Bartha, K. Kennedy, and R. Chhem, "MRI and multinuclear MR spectroscopy of 3,200-year-old Egyptian mummy brain," American Journal of Roentgenology, vol. 189, no. 2, pp. W105-W110, 2007.

[27] L. Zweifel, T. Büni, and F. J. Rühli, "Evidence-based palaeopathology: meta-analysis of PubMed-listed scientific studies on ancient Egyptian mummies," HOMO, vol. 60, no. 5, pp. 405427, 2009.

[28] J. Wanek, R. Speller, and F. J. Rühli, “Direct action of radiation on mummified cells: modeling of computed tomography by Monte Carlo algorithms," Radiation and Environmental Biophysics, vol. 52, no. 3, pp. 397-410, 2013.

[29] E.-J. Lee, C. S. Oh, S. G. Yim et al., "Collaboration of archaeologists, historians and bioarchaeologists during removal of clothing from Korean Mummy of Joseon Dynasty," International Journal of Historical Archaeology, vol. 17, no. 1, pp. 94-118, 2013.

[30] M. R. Zimmerman and A. C. Aufderheide, "The frozen family of Utqiagvik: the autopsy findings," Arctic Anthropology, vol. 21, pp. 53-64, 1984.

[31] M. A. Ruffer, "Pathological notes on the royal mummies of the Cairo Museum," in Studies in the Paleopathology of Egypt, R. L. Moodle, Ed., pp. 166-178, University of Chicago Press, Chicago, Ill, USA, 1921.

[32] P. J. Turner and D. B. Holtom, "The use of a fabric softener in the reconstitution of mummified tissue prior to paraffin wax sectioning for light microscopical examination," Stain Technology, vol. 56, no. 1, pp. 35-38, 1981.

[33] E. Fulcheri, E. Rabino Massa, and C. Fenoglio, "Improvement in the histological technique for mummified tissue," Verhandlungen der Deutschen Gesellschaft für Pathologie, vol. 69, p. 471, 1985.

[34] A.-M. Mekota and M. Vermehren, "Determination of optimal rehydration, fixation and staining methods for histological and immunohistochemical analysis of mummified soft tissues," Biotechnic \& Histochemistry, vol. 80, no. 1, pp. 7-13, 2005.

[35] A. C. Aufderheide, "History of mummy studies," in The Scientific Study of Mummies, A. C. Aufderheide, Ed., pp. 1-17, Cambridge University Press, Cambridge, UK, 2003.

[36] M. Manialawi, R. Meligy, and M. Bucaille, "Endoscopic examination of Egyptian mummies," Endoscopy, vol. 10, no. 3, pp. 191194, 1978.

[37] G. Castillo-Rojas, M. A. Cerbón, and Y. López-Vidal, "Presence of Helicobacter pylori in a Mexican pre-columbian mummy," BMC Microbiology, vol. 8, article 119, 2008.

[38] E. Tapp, "Histology and histopathology of the Manchester mummies," in Science in Egyptology, A. R. David, Ed., pp. 347350, Manchester University Press, Manchester, UK, 1986.

[39] F. Collini, S. A. Andreola, G. Gentile, M. Marchesi, E. Muccino, and R. Zoja, "Preservation of histological structure of cells in human skin presenting mummification and corification processes by Sandison's rehydrating solution," Forensic Science International, vol. 244, pp. 207-212, 2014.

[40] G. Grévin, R. Lagier, and C.-A. Baud, "Metastatic carcinoma of presumed prostatic origin in cremated bones from the first century A.D," Virchows Archiv, vol. 431, no. 3, pp. 211-214, 1997. 
[41] G. Kahila Bar-Gal, M. J. Kim, A. Klein et al., "Tracing hepatitis $\mathrm{B}$ virus to the 16th century in a Korean mummy," Hepatology, vol. 56, no. 5, pp. 1671-1680, 2012.

[42] F. Musshoff, C. Brockmann, B. Madea, W. Rosendahl, and D. Piombino-Mascali, "Ethyl glucuronide findings in hair samples from the mummies of the Capuchin Catacombs of Palermo," Forensic Science International, vol. 232, no. 1-3, pp. 213-217, 2013.

[43] A. H. Thompson, A. S. Wilson, and J. R. Ehleringer, "Hair as a geochemical recorder: ancient to modern," in Treatise on Geochemistry (Volume 14): Archaeology \& Anthropology, T. E. Cerling, Ed., pp. 371-393, Elsevier, Cambridge, UK, 2nd edition, 2014.

[44] A. S. Wilson, E. L. Brown, C. Villa et al., "Archaeological, radiological, and biological evidence offer insight into Inca child sacrifice," Proceedings of the National Academy of Sciences of the United States of America, vol. 110, no. 33, pp. 13322-13327, 2013.

[45] R. Bianucci, M. Jeziorska, R. Lallo et al., "A pre-hispanic head," PLoS ONE, vol. 3, no. 4, Article ID e2053, 2008.

[46] G. Lombardi, A. Lanzirotti, C. Qualls, F. Socola, A.-M. Ali, and O. Appenzeller, "Five hundred years of mercury exposure and adaptation," Journal of Biomedicine and Biotechnology, vol. 2012, Article ID 472858, 10 pages, 2012.

[47] A. Lanzirotti, R. Bianucci, R. LeGeros et al., "Assessing heavy metal exposure in Renaissance Europe using synchrotron microbeam techniques," Journal of Archaeological Science, vol. 52, pp. 204-217, 2014.

[48] V. A. Sawicki, M. J. Allison, H. P. Dalton, and A. Pezzia, "Presence of Salmonella antigens in feces from a Peruvian mummy," Bulletin of the New York Academy of Medicine: Journal of Urban Health, vol. 52, no. 7, pp. 805-813, 1976.

[49] R. Bianucci, G. Mattutino, R. Lallo et al., "Immunological evidence of Plasmodium falciparum infection in an Egyptian child mummy from the early dynastic period," Journal of Archaeological Science, vol. 35, no. 7, pp. 1880-1885, 2008.

[50] A. Corthals, A. Koller, D. W. Martin et al., "Detecting the immune system response of a 500 year-Old Inca Mummy," PLoS ONE, vol. 7, no. 7, Article ID e41244, 2012.

[51] W. L. Salo, A. C. Aufderheide, J. Buikstra, and T. A. Holcomb, "Identification of Mycobacterium tuberculosis DNA in a preColumbian Peruvian mummy," Proceedings of the National Academy of Sciences of the United States of America, vol. 91, no. 6, pp. 2091-2094, 1994.

[52] A. G. Nerlich, C. J. Haas, A. Zink, U. Szeimies, and H. G. Hagedorn, "Molecular evidence for tuberculosis in an ancient Egyptian mummy," The Lancet, vol. 350, no. 9088, p. 1404, 1997.

[53] É. Crubézy, B. Ludes, J. D. Poveda, J. Clayton, B. Crouau-Roy, and D. Montagnon, "Identification of Mycobacterium DNA in an Egyptian Pott's disease of 5400 years old," Comptes Rendus de Académie des Sciences-Serie III, vol. 321, no. 11, pp. 941-951, 1998.

[54] A. Zink, C. J. Haas, U. Reischl, U. Szeimies, and A. G. Nerlich, "Molecular analysis of skeletal tuberculosis in an ancient Egyptian population," Journal of Medical Microbiology, vol. 50, no. 4, pp. 355-366, 2001.

[55] A. R. Zink, W. Grabner, U. Reischl, H. Wolf, and A. G. Nerlich, "Molecular study on human tuberculosis in three geographically distinct and time delineated populations from Ancient Egypt," Epidemiology and Infection, vol. 130, no. 2, pp. 239-249, 2003.

[56] A. R. Zink, C. Sola, U. Reischl et al., "Characterization of Mycobacterium tuberculosis complex DNAs from Egyptian mummies by spoligotyping," Journal of Clinical Microbiology, vol. 41, no. 1, pp. 359-367, 2003.

[57] A. R. Zink and A. G. Nerlich, "Molecular analyses of the 'Pharaos:' feasibility of molecular studies in ancient Egyptian material," American Journal of Physical Anthropology, vol. 121, no. 2, pp. 109-111, 2003.

[58] A. R. Zink and A. G. Nerlich, "Long-term survival of ancient DNA in Egypt: reply to Gilbert et al," American Journal of Physical Anthropology, vol. 128, pp. 115-118, 2005.

[59] A. R. Zink, M. Spigelman, B. Schraut, C. L. Greenblatt, A. G. Nerlich, and H. D. Donoghue, "Leishmaniasis in Ancient Egypt and Upper Nubia," Emerging Infectious Diseases, vol. 12, no. 10, pp. 1616-1617, 2006.

[60] A. C. Aufderheide, W. Salo, M. Madden et al., "A 9,000-year record of Chagas' disease," Proceedings of the National Academy of Sciences of the United States of America, vol. 101, no. 7, pp. 2034-2039, 2004.

[61] A. G. Nerlich, B. Schraut, S. Dittrich, T. Jelinek, and A. R. Zink, "Plasmodium falciparum in Ancient Egypt," Emerging Infectious Diseases, vol. 14, no. 8, pp. 1317-1319, 2008.

[62] Z. Hawass, Y. Z. Gad, S. Ismail et al., "Ancestry and pathology in King Tutankhamun's family," The Journal of the American Medical Association, vol. 303, no. 7, pp. 638-647, 2010.

[63] H. D. Donoghue, O. Y.-C. Lee, D. E. Minnikin, G. S. Besra, J. H. Taylor, and M. Spigelman, “Tuberculosis in Dr Granville's mummy: a molecular re-examination of the earliest known Egyptian mummy to be scientifically examined and given a medical diagnosis," Proceedings of the Royal Society B: Biological Sciences, vol. 277, no. 1678, pp. 51-56, 2010.

[64] H. D. Donoghue, "Insights gained from palaeomicrobiology into ancient and modern tuberculosis," Clinical Microbiology and Infection, vol. 17, no. 6, pp. 821-829, 2011.

[65] A. Lalremruata, M. Ball, R. Bianucci et al., "Molecular identification of falciparum malaria and human tuberculosis coinfections in mummies from the Fayum Depression (Lower Egypt)," PLoS ONE, vol. 8, no. 4, Article ID e60307, 2013.

[66] J. Z.-M. Chan, M. J. Sergeant, O. Y.-C. Lee et al., "Metagenomic analysis of tuberculosis in a mummy," The New England Journal of Medicine, vol. 369, no. 3, pp. 289-290, 2013.

[67] R. Khairat, M. Ball, C.-C. H. Chang et al., "First insights into the metagenome of Egyptian mummies using next-generation sequencing," Journal of Applied Genetics, vol. 54, no. 3, pp. 309325, 2013.

[68] E. Anastasiou and P. D. Mitchell, "Palaeopathology and genes: investigating the genetics of infectious diseases in excavated human skeletal remains and mummies from past populations," Gene, vol. 528, no. 1, pp. 33-40, 2013.

[69] M. T. P. Gilbert, I. Barnes, M. J. Collins et al., "Long-term survival of ancient DNA in Egypt: response to Zink and Nerlich," American Journal of Physical Anthropology, vol. 128, no. 1, pp. 115-118, 2005.

[70] E. D. Lorenzen and E. Willerslev, "King Tutankhamun's family and demise," Journal of the American Medical Association, vol. 303, no. 24, pp. 2471-2475, 2010.

[71] J. Marchant, "Ancient DNA: curse of the Pharaoh's DNA," Nature, vol. 472, no. 7344, pp. 404-406, 2011.

[72] G. Piñar, D. Piombino-Mascali, F. Maixner, A. Zink, and K. Sterflinger, "Microbial survey of the mummies from the Capuchin Catacombs of Palermo, Italy: biodeterioration risk and contamination of the indoor air," FEMS Microbiology Ecology, vol. 86, no. 2, pp. 341-356, 2013. 
[73] J. Koller, U. Baumer, Y. Kaup, H. Etspuler, and U. Weser, "Embalming was used in Old Kingdom," Nature, vol. 391, no. 6665, pp. 343-344, 1998.

[74] R. P. Evershed, K. I. Arnot, J. Collister, G. Eglinton, and S. Charters, "Application of isotope ratio monitoring gas chromatography-mass spectrometry to the analysis of organic residues of archaeological origin," The Analyst, vol. 119, no. 5, pp. 909-914, 1994.

[75] S. A. Buckley, A. W. Stott, and R. P. Evershed, "Studies of organic residues from ancient Egyptian mummies using high temperature-gas chromatography-mass spectrometry and sequential thermal desorption-gas chromatography-mass spectrometry and pyrolysis-gas chromatography-mass spectrometry," Analyst, vol. 124, no. 4, pp. 443-452, 1999.

[76] S. A. Buckley, K. A. Clark, and R. P. Evershed, "Complex organic chemical balms of Pharaonic animal mummies," Nature, vol. 431, no. 7006, pp. 294-299, 2004.

[77] J. Jones, T. F. Higham, R. Oldfield, T. P. O’Connor, S. A. Buckley, and L. Bondioli, "Evidence for prehistoric origins of Egyptian mummification in late Neolithic burials," PLOS ONE, vol. 9, no. 8, Article ID e103608, 2014.

[78] S. Buckley, D. Usai, T. Jakob, A. Radini, K. Hardy, and D. Guatelli-Steinberg, "Dental calculus reveals unique insights into food items, cooking and plant processing in prehistoric central Sudan," PLoS ONE, vol. 9, no. 7, Article ID e100808, 2014.

[79] A. C. Aufderheide, L. R. Cartmell, M. Zlonis, and P. Horne, "Chemical dietary reconstruction of Greco-Roman mummies at Egypt's Dakhleh Oasis," The Journal of the Society for the Study of Egyptian Antiquities, vol. 30, pp. 1-10, 2003.

[80] H. Pringle, The Mummy Congress. Science, Obsession, and the Everlasting Dead, Hyperion, New York, NY, USA, 2001.

[81] S. Holm, "The privacy of Tutankhamen-utilising the genetic information in stored tissue samples," Theoretical Medicine and Bioethics, vol. 22, no. 5, pp. 437-449, 2001.

[82] R. Downey, Riddle of the Bones: Politics, Science, Race, and the Story of Kennewick Man, Springer, Copernicus, New York, NY, USA, 2000.

[83] I. M. Kaufmann and F. J. Rühli, "Without 'informed consent'? Ethics and ancient mummy research," Journal of Medical Ethics, vol. 36, no. 10, pp. 608-613, 2010.

[84] P. Lambert-Zazulak, "The international ancient Egyptian mummy tissue bank at the Manchester Museum," Antiquity, vol. 74, no. 283, pp. 44-48, 2000. 

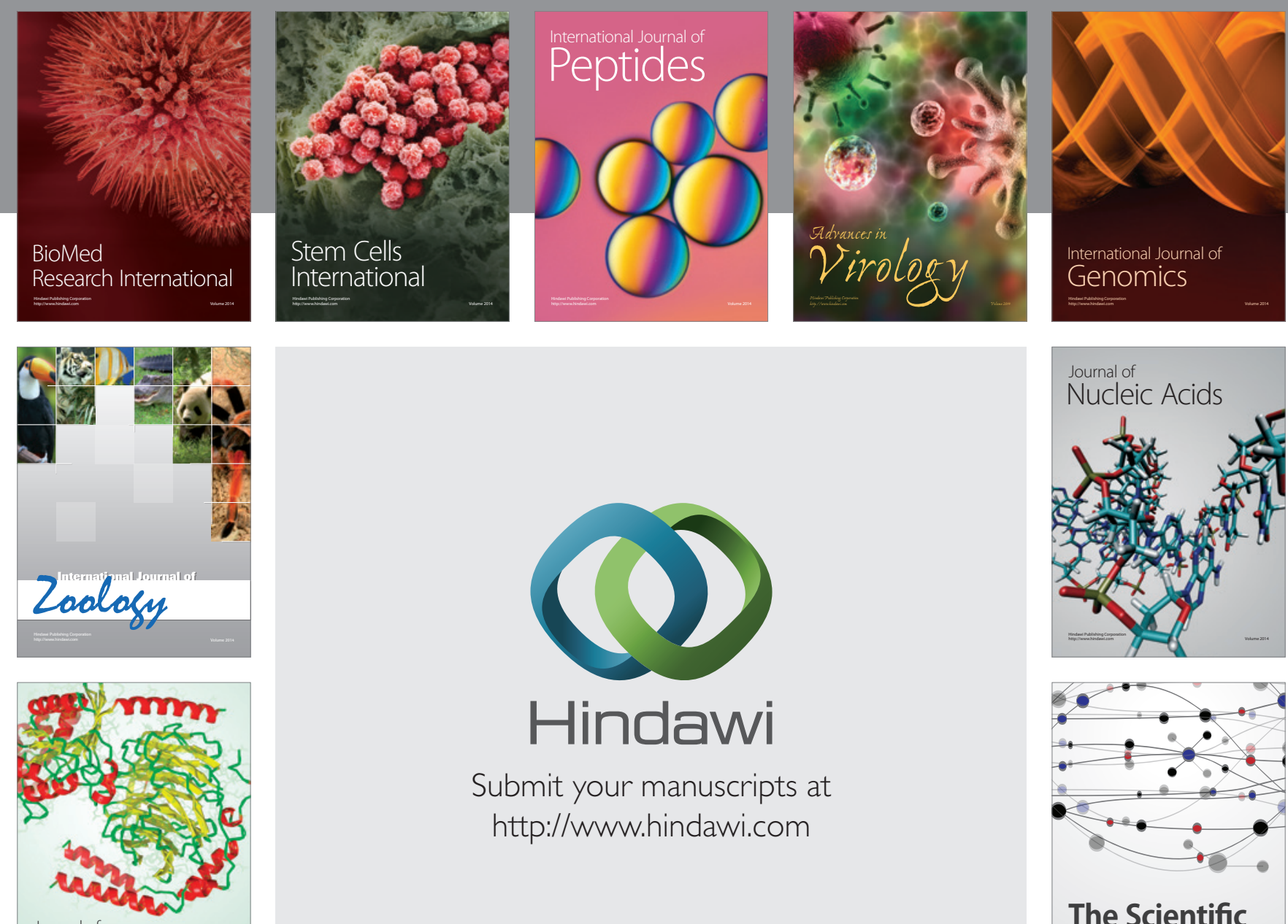

Submit your manuscripts at

http://www.hindawi.com

Journal of
Signal Transduction
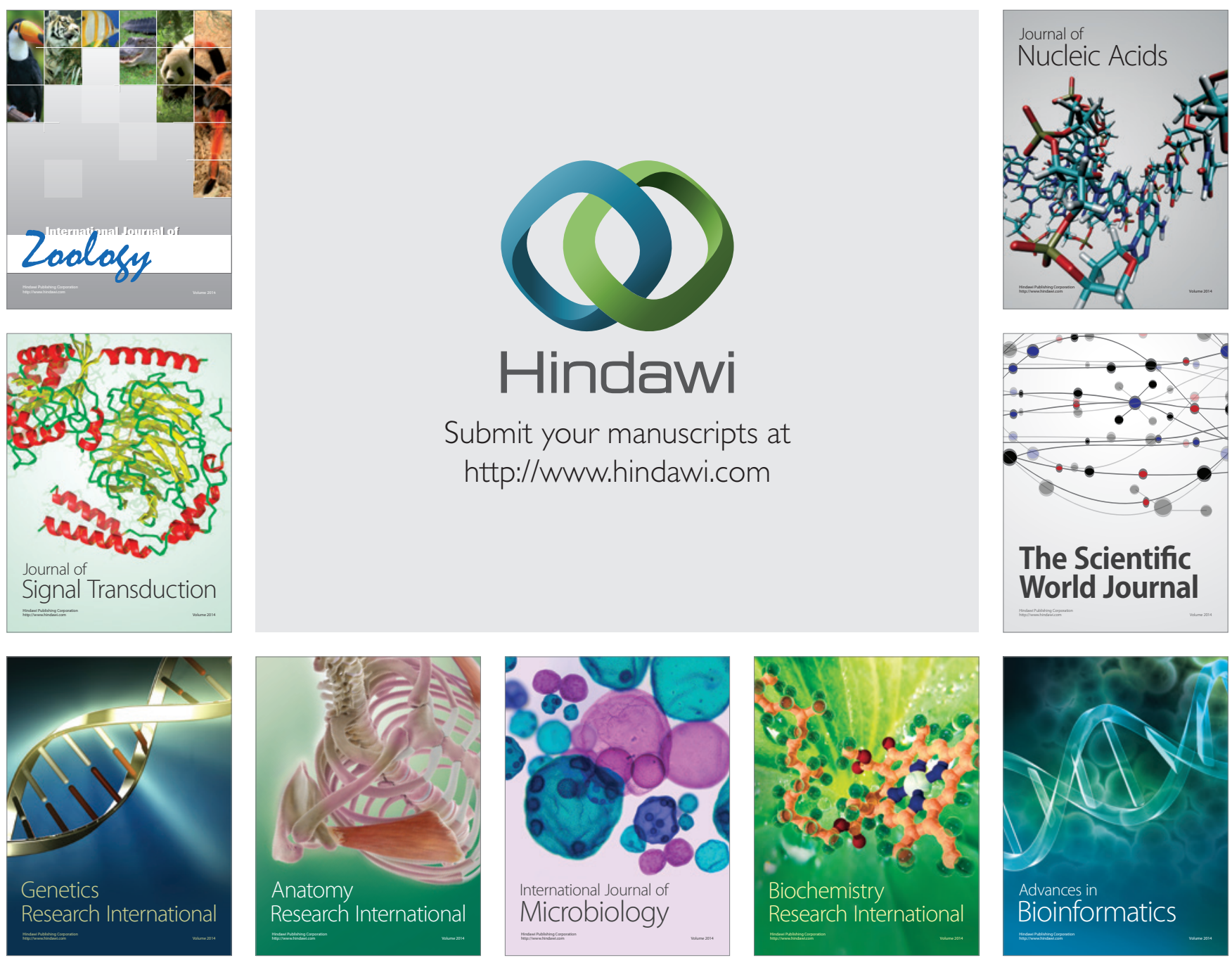

The Scientific World Journal
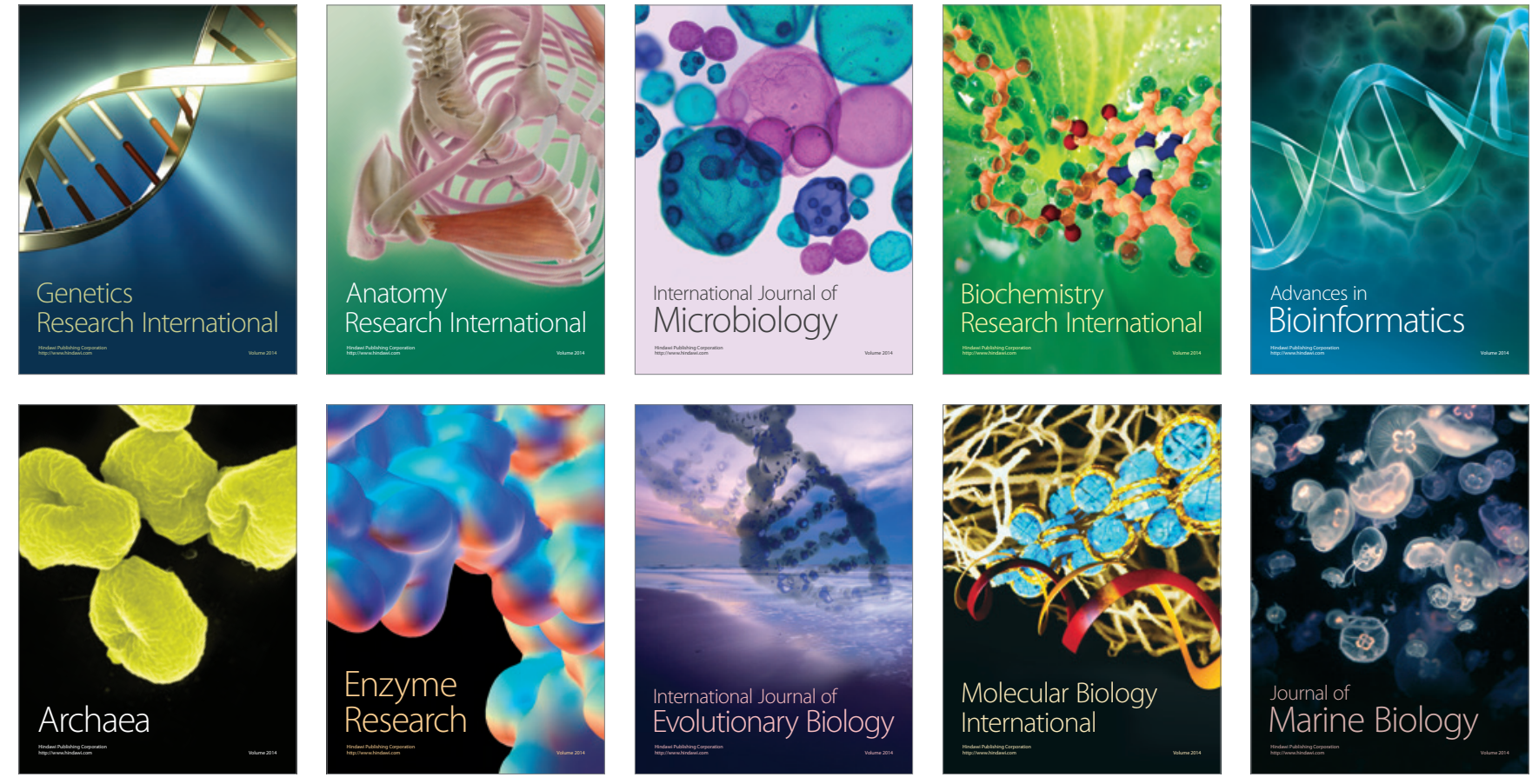